\title{
Proposal to New Jersey Department of Health for Modification of New Employees' Orientation
}

\author{
Chinazo Echezona-Johnson \\ ASA College of Nursing, New York
}

This paper is about a program proposal for New Jersey Department of Health to find an alternative way to conduct their orientation training to be appropriate for adult learners, and to meet the four key elements of learning- motivation, reinforcement, retention, and transference. The proposed project will train New Jersey educators how to modify the orientation training using the adult learning principles of Knowles' Andragogy to help them to design the teaching methodologies that are useful for adults from different educational, cultural and developmental backgrounds. The proposed program will consist of the basic phases of program planning include needs assessment, program outcomes and learning objectives, transfer of learning, program structure, and program evaluation. Two informal and one formal method or strategies for gathering data needs/ideas were designed. One informal and two formal methods or strategies for program evaluation data were also designed to determine the program effectiveness and future direction. The program structure, timeframe and resources were explained in detail. An instructional plan and program budget were developed and included.

Keywords: helping others, aid, assistance, entitlement, toxic charity

\section{INTRODUCTION}

Social \& Organizational Context of the Learning Environment: The Learning/Work Environment

The New Jersey Department of Human Services (DHS) serves the most vulnerable citizens of New Jersey. The eight divisions of the department serve,

"... individuals and families with low incomes; people with mental illnesses, developmental disabilities, or late-onset disabilities; people who are blind, visually impaired, deaf, hard of hearing, or deaf-blind; parents needing child care services, child support and/or healthcare for their children; and families facing catastrophic medical expenses for their children..." (State of New Jersey, n.d., p.1).

With a budget of over $\$ 10$ billion and more than 14,000 employees, it is one of New Jersey's largest agencies. The DHS serves nearly one million people and deals with a host of not-for-profit organizations, advocacy, and constituency groups. The DHS depends a great deal on the public in its decision-making process and is accountable to many stakeholders. 


\section{Primary Stakeholders}

The major stakeholders are: the State Human Services Advisory Council and advocacy groups such as the workers' union and Patient Safety group; the New Jersey administrators and civic and community leaders. With the political and economic crisis in the state, all the stakeholders are concerned about providing quality and affordable services to the patients and protecting the interests of the state, patients, and workers. The state human services advisory council and the New Jersey administrators worry about using the allocated budget to operate the hospitals. The patient safety group is concerned with patient safety and the quality of services the patients are receiving. The workers' unions worry about the welfare of the New Jersey workers and their compensation.

\section{Major Strengths and Opportunities Within the Environment}

The New Jersey Department of Health, a division of the Jersey Department of Human Services (DHS), has its strengths and opportunities in the accreditation and recognition by and federal and state regulators. It has bureaucratic and financial support from the state administration; an array of qualified and certified human resources; and qualified educational personnel. In addition, the department has the potential to retain more educational personnel with advanced qualifications and certifications.

\section{Immediate Issue(s), Concerns, Gaps, or Trends}

The New Jersey Department of Health hires over 50 professional and non-professional health care workers every month. These employees' ages range from 21 to 60 years old. These new recruits come from different educational backgrounds, are from different cultural and racial backgrounds, and have a variety of experiences. To comply with the state and federal mandates, these new workers must go through four weeks of paid, mandatory orientation training. By the end of the orientation, less than one-quarter of these new employees stay. The other three- quarters resign out of frustration or fired for incompetence.

\section{Contextual Factors Influencing the Situation}

One of the contextual factors that are affecting this situation is finances of the State. Due to the State's budget cuts, the staff developmental department, responsible for the orientation, functions with a skeleton staff of one director, one full-time and one part-time secretary, two full-time educators and per diem instructors and student interns.

\section{Alignment With the Organization's Mission}

Given the importance of the orientation program for the hospitals, the purpose of this paper is to propose to the New Jersey Department of Health an alternative way to conduct their orientation training to be appropriate for adult learners, and to meet the four key elements of learning- motivation, reinforcement, retention, and transference (Lieb, 1991). Successful orientation training begins from the date of hire and continues to the first year of service. The training program becomes the "stepping-stone" for other programs such as the annual review and performance reviews (Barbazette, n.d).

The proposed project will use Knowles' Andragogy adult learning principles to modify the orientation training, and design the teaching methodologies that are useful for adults from different educational, cultural and developmental backgrounds. Andragogy relates to the growing body of knowledge and technology about adult learning; the art and science of helping adults learn. In his book, Knowles enumerated six assumptions of Andragogy that distinguishes Andragogy from pedagogy. According to Knowles, adult students,

"... need learning to be meaningful; they are autonomous, independent, and self- directed; prior experiences are a rich learning resource; their readiness to learn is associated with a transition point or a need to perform a task; their orientation is centered on problems, not content; they are intrinsically motivated; their participation in learning is voluntary" (Kerka, 2002). 
This program proposal will be in alignment with the Department of Human Services (DHS) mission, which is its dedication,

“... to providing quality services that consistently meet expectations with the goal to protect, assist and empower economically disadvantaged individuals and families, and people with disabilities to achieve their maximum potential. We strive to ensure a seamless array of services through partnerships and collaborations with communities statewide. We seek to promote accountability, transparency, and quality in all that we do" (State of New Jersey, n.d., p.1).

\section{Needs Assessment Plan}

In this section, three processes for gathering data will be provided. The three methods are adapted and modified from other pre-established instruments. The processes are a Likert survey, an informal focus group interview, and an observational checklist (see Appendices 1, 2, 3 and 4). All the instruments' findings are protected and will be kept confidential. The results will be reported via the agency's email and during formal staff meeting. The results will be used to plan a new employee orientation for the State of New Jersey, DHS.

According to stakeholders, the New Jersey Department is not adequately preparing and supporting newly hired staff. Consequently, these caregivers end up jeopardizing the patients' safety. The lack of retention of these newly hired personnel causes DHS to spend a lot of money to replace these caregivers and to staff the in-patient units.

\section{LIKERT SURVEY SCALE}

Likert surveys are instruments that are used to collect quantitative data (see Appendices 1 and 2). The purpose of the two Likert scale surveys are to collect the biography of the New Jersey educators, and assess their use of adult learning principles when they conduct new employee orientations.

\section{Guiding Questions for Demographics}

a. Number of years teaching?

b. Number of years teaching at New Jersey State Department?

c. What is Number of years working "in your chosen field?"

d. Highest level of education's program of study (Communication, Accounting, Nursing, Medicine etc.)?

e. Number of years working "in your chosen field?" (See appendix 1).

\section{Guiding Questions for Needs Assessment}

Do you:

a. use disciplinary action when it is needed?

b. encourage students to adopt middle class values?

c. plan units, which differ widely as possible from my students' socio-economic backgrounds?

d. get a student to motivate himself/herself by confronting him/her in the presence of classmates during group discussions?

e. participate in the informal counseling of students?

f. gear instructional objectives to match the individual abilities and needs of the students?

g. encourage dialogue among my students?

utilize the many competencies that most adults already possess to achieve educational objectives?

avoid discussion of controversial subjects that involve value judgments help students? relate new learning to their prior experiences? (see appendix). 


\section{Implementation}

The instruments will be given to all the full-time, part-time and per diem New Jersey educators via their mailboxes. Information gathered will be saved in a confidential, password- protected folder on the planner's personal computer

\section{Process and Field Test}

Since the scale is adapted from another instrument, pilot testing will be used to assess the reliability and validity of this instrument. Five to ten educators will be recruited to do a pilot test of the instrument. Instrument will be checked to see if it measures consistency over time and check for internal consistency. That is the consistency within the instrument, " ... the correlations between each item and the overall score on the instrument" (Lodico et al., p. 92). In other words, to ensure that the instrument measures what it is supposed to measure.

\section{Data Analysis and Reporting}

Descriptive statistics- mode, median and mean - will be used to summarize the demographics of the educators. The mean and frequency will be used to determine if and what adult education strategies the New Jersey educators are using. Standard deviation will be used to examine how each educator's score deviates from the mean. Findings will be reported via state's interoffice email and handouts at a formal staff meeting.

\section{INFORMAL FOCUS GROUP/ SEMI-STRUCTURED INTERVIEW}

Informal Focus Group/ Semi-Structured Interview will be used to gather information from NJ employees so that the new employees'orientation will be improved (see Appendix 3).

\section{Guiding Questions}

Questions will revolve around these issues:
a. Reflection on past orientations
b. Discuss the present orientation
c. Ideas for future orientations

\section{Process}

There will be a stratified random selection process for New Jersey employees. The selected employees will be divided into 5 or 6 groups of:

- Educators

- Administrative staff

- New employees less than one year

- Current Employees more than one year to five years

- Long term employees more than five years

\section{Implementation}

Utilizing a random sample process will ensure that individuals from all the state's divisions will be selected. The goal is to include 100 faculty/staff in the data collection process. Each person who is randomly selected will have the option to participate in the 1:1 interview or a focus group. Invitation will be sent to all State employees for a series of six focus groups conducted at various times and locations for employee convenience. Interviews will be taped.

\section{Data Analysis and Reporting}

All information collected will be kept confidential. Data will be analyzed by looking for themes. Information will be disseminated through staff meetings and via state's interoffice emails. 


\section{FORMAL OBSERVATION CHECKLIST}

Formal Observation Checklist will be used to observe the teaching techniques of the educators. It will “... provide a level of rigor to the data collection process and ensure that the data are reliable and valid... and help standardize the observations" (Lodico et al., 2010, p.113).

\section{Guiding Questions}

Did the educator:

1. provide review of previous work as a warm-up exercise for students?

2. reviewed lesson objectives and reviewed the agenda?

3. provide opportunities for students to become familiar with lesson materials?

4. check students' background knowledge on the topic/lesson?

5. use appropriate presentation style(s) for content and audience? (For the rest of the questions see the tool in Appendix 4).

\section{Implementation}

Two education graduate students from New Jersey Seton Hall University will be recruited to conduct the observations. Two observers will be trained how to use the observation checklist. The two observers will be kept in the "blind" about the expected outcomes of the observation. T his blind procedure will help to avoid observer bias.

\section{Process and Field Test}

The observations will occur during the new employees' orientations. The observers will be trained to keep the observations short, be alert on behaviors and activities of the participants and concentrate on specifics. The observers will record both descriptive and reflective field notes (Lodico et al., 2010). To show that the tool is reliable, I will use inter-rater reliability to measure consistency between the two observers.

\section{Data Analysis and Reporting}

Data will be analyzed by reading the observers' comments to detect themes. The themes will be summarized and discussed in a formal staff meeting. All information will be stored in a locked safe in the researcher's office and a confidential folder on the computer.

\section{PROGRAM}

\section{Problem Statement}

In a recent presentation to the New Jersey Department of Health executive staff, report show that the hospitals are losing most of their operating budget to train new employees that do not stay or do not perform competently outside the classrooms. Studies show that medical errors and negligence occur when hospitals are understaffed, or staffed by outside agencies (Rice, 2003). Another problem is the added stress suffered by other health care providers that must serve the patients short-handed (Lacey et al., 2003). Additionally, patients' safety and well-being are compromised.

To operate the hospital units adequately, safely, and meet the standards for accreditation by healthcare regulators, the New Jersey State Department of health is regularly hiring very expensive outside agencies to staff the patients' units. Additionally, the State is spending a lot of money settling lawsuits stemming from these medical errors and negligence litigation.

\section{Desired Knowledge, Skills, and Attitudes}

These problems are preventable through a well-developed orientation training program (AHRQ, n.d.; $\&$ Joint Commission, 2005). The proposed program entails training New Jersey educators to use adult learning principles the new employees' orientation. The expected knowledge, skills, attitudes, and beliefs 
that will be transferred from the learning environment to real life are: the knowledge of adult learning principles; instructional techniques that incorporate adult learning principles; and different ways and change in attitudes about adult learner retention and motivation.

\section{Program Outcomes}

The proposed program will:

1. Establish an alternative way to conduct the new employees' orientation, training appropriately for adult learners.

2. Institute a mentoring program for all staff.

3. Create a formal competency assessment of newly hired employees

\section{Learning Objectives for Program Outcome \#1}

At the end of the program, participants will be able to:

1. explain four adult learning principles

2. discuss six instructional techniques that incorporate adult learning principles

3. demonstrate three ways to motivate the adult learner

\section{Key People to Ensure the Transfer of Learning}

The people who are essential to ensure the transfer of learning are: the New Jersey administrators such as: direct supervisors, clinical directors, human resources staff, union officers and representatives, civic and community leaders, and the clinical and non-clinical staff. Direct supervisors and clinical managers will help support the educators to transfer their newly acquired skills during monthly orientations. Also, these key people can assist in designing, delivering and assessing the proposed program.

Human resources staff, union officers, and representatives, civic and community leaders, will ensure transfer of learning by updating policies to reflect the educators' new skills. Also, they can approve and award monetary rewards for transferring desired skills.

The clinical and non-clinical staff will support the transfer of learning by working with the educators to serve as mentors to the new employees.

\section{Possible Transfer of Learning Strategies and Techniques}

To determine the transfer of learning strategies and techniques that will be used, the educators will be assessed with the Stages of Concerns model by Hall and Hord. Strategies will be used depending on the educators' preferences, resource availability and the knowledge and skills that will be transferred (Caffarella, 2002). Some of the strategies that will be used are: individual coaching and mentoring of the educational staff to use their newly acquired skills when modifying the orientation program. Also, educators will be provided with follow-up sessions to "... reinforce and extend the learning from the original activity" (Cafferella, 2002, p. 229, Exhibit 10.2).

\section{Process for Monitoring During and After the Implementation}

During the program, a process for monitoring will be established by asking the educators to use their new skills and report back if it is helpful, and to use techniques that will allow them to transfer their skill. After the implementation, the educators will be provided with follow-up assistance and encouraged to adapt their new skills to the orientation as needed.

\section{Program Structure and Format}

The purpose of the program is to teach NJ educators new ways to conduct the new employees' orientation that is appropriate for adult learners. The program format will be six small groups of $20 \mathrm{New}$ Jersey educators for each session. The format will be workshops. The emphasis will be "... on group participation and the transfer and application of new learning" (Fleming, 1997 as cited in Cafferella, 2001, p. 240). (see appendix 5). 


\section{Timeframe and Resources}

The program will be conducted in between monthly orientations for three hours with 30 minutes break time. Since the State is going through financial recession, the program will be planned using cost effective strategies. For instance, the program will need two external instructors for the six sessions. External instructors will give the New Jersey educators opportunity to learn new things from expert people in the industry. The external instructors will assist the educators to achieve the program objectives by designing and delivering the program. Two internal staff will be used for coordination and evaluation of the program as a way to reduce costs (see Appendix 6).

Also, the workshops will take place in a large classroom or a large conference room in one of the State's campuses. The state classrooms and conference rooms are conducive to learning and are technology-ready rooms. Instructional resources such as power points, posters, LCD's, will be used. Refreshments will be served to promote the comfort of the educators.

The program will be promoted by the state by weekly emails and memos reminders. The seating will be a team style arrangement with seats of five around oblong tables. Team style arrangement seating encourages team interaction (Cafferella, 2002, p. 298). (See Appendix 5 and 6).

\section{PROGRAM EVALUATION}

\section{Brief Synopsis of the Program Proposal Being Evaluated}

The proposed project will use adult learning principles of Knowles Andragogy to modify the new employees' orientation, and design teaching methodologies that are useful for adults from different educational, cultural and developmental backgrounds.

\section{Questions Guiding the Evaluation}

A list of questions guiding the evaluation:

1. Were the objectives of the program addressed in an effective and efficient manner?

2. Were the learners able to apply what they learned back into their work?

3. What new skills were learned by participants as a result of the program?

4. Was there a reduction in the rate of turnover of new employees that could be attributed to the orientation program?

5. As a result of the program, are the NJ educators more effective instructors?

\section{FORMAL LIKERT SCALE - TRANSFER OF LEARNING}

Formal Likert Survey scale will be used to:

- measure the teaching techniques of the educators

- monitor if the educators were able to apply what they learned back into their work settings

- evaluate the new skills learned by participants as a result of the program

- assess if the NJ educators were more effective instructors as a result of the program

\section{Process and Field Test}

The instrument will be implemented one month after the workshop through the emails and interoffice emails. Instrument will be used on a pilot group of five to ten educators to check for reliability, construct, item and content validity.

\section{Guiding Questions and Implementation}

For guiding questions (Appendix 3). The survey will be disseminated to the educators at the end of the program and three months after the program. Survey will get their feedback immediately after the program and after they have used their newly learned skills. 


\section{Data Analysis and Reporting}

Data will be analyzed using descriptive statistics (frequency, mode, median, mean (Lodico, 2006, p. 75-81) and using a graph to report the results to the stakeholders during the executive meetings. All information will be stored in a locked safe in the researcher's office and a confidential folder on the computer. Locking the data will ensure the confidentiality of the information.

\section{FORMAL LIKERT SURVEY SCALE - ORIENTATION EVALUATION}

The Likert scale questionnaire will be used to evaluate the orientation modification program for New Jersey educators to see if the objectives of the program were addressed in an effective and efficient manner.

\section{Process, Field test, Guiding Questions, and Implementation}

Formal Likert Survey scale will be disseminated through the emails, interoffice-mails and as a handout. Prior to dissemination, instrument will be used on a pilot group to check for reliability, construct, item and content validity. For guiding questions, (see survey scale, Appendix 8). The survey will be disseminated to the educators at the end of the program and three months after the program. Survey will get their feedback immediately after the program and after they have used their newly learned skills.

\section{Data Analysis and Reporting}

Data will be analyzed using descriptive statistics (frequency, mode, median, mean (Lodico, 2006, p. 75-81) and using a graph to report the results to the stakeholders during the executive meetings. All information will be stored in a locked safe in the researcher's office and a confidential folder on the computer. Locking the data will ensure the confidentiality of the information.

\section{INFORMAL INTERVIEW - EVALUATION}

\section{Purpose, Process and Implementation, Field Test}

Informal Interview will be used informally to interview the educators about the effectiveness of the program and how they will transfer their newly acquired skills and knowledge to the orientations. The informal interview will occur formatively during breaks and in informal settings such as bathrooms, coffee areas, etc.

\section{Guiding Questions, Data Analysis and Reporting}

Some of the issues that may be asked included but not limited to these questions:

1. How is the session so far?

2. Do you think that it will help you with doing the orientation program?

3. What are some of the new skills that you have learned from this session?

4. Do you think that this program will help you become better as an educator?

All information collected will be confidential. Information will be recorded and confidentially stored in a confidential folder. Results will be shared with the program external and internal instructors, verbally and by emails. This information will be used to restructure the ongoing program and to develop future programs.

\section{PROGRAM LEARNING TASKS}

\section{Purposes Learning Task One}

The first learning task is that the learners will comprehend Knowles's Andragogy. This learning task will encourage New Jersey educators actively to process the information about adult learning principles. The tasks will help the educators to accomplish their learning objectives. According to the literature, learning develops when the learning task encourages the learner actively to process the information (Cafferella, 2002; Galbraith, 2004). 


\section{Alignment With Outcomes and Objectives/Prerequisites/Target Population/Group Size}

To be able to establish an alternative way to conduct the new employees' orientation, training appropriately to be for adult learners, participants will be able to understand Knowles's principles of adult learning. The prerequisites for this program for the educators are the mandatory participation in the needs assessment survey and must have read one article about Andragogy and two articles on adult motivation. The target population is the New Jersey Department of Health educators. The group size will be small size group which will consist of six New Jersey educators.

\section{SECTION 2: LEARNING ACTIVITY/STRUCTURE AND FORMAT OF THE PROGRAM}

\section{Instructional Method}

The instructional methods that will emphasize "... group participation and the transfer and application of new learning" (Fleming, 1997 as cited in Cafferella, 2002, p. 240). The program format for this learning task will be for six small groups of 24 New Jersey educators for each session. Each group will consist of six educators. The format will be workshops made up of mini-lectures, small group discussions; problembased learning, observations, simulations, reflective practice. Varieties of instructional formats will give the New Jersey educators opportunity to acquire new things from expert people in the industry.

\section{Instructional Resources/Learning Accommodations/Time Frame}

The instructional resources for the instructors such as power points, posters, LCD's, will be used. The resources for the participants will be: Reference lists for Andragogy, PowerPoint Handouts, Principles of Adult Learning Scale by Gary Conti, Peer reviewed articles, and extra papers and pens. The workshop will occur in a large New Jersey Department Of health auditorium. The type of seating will be a team style arrangement with seats of five around oblong tables. This kind of arrangement promotes team interaction (Cafferella, 2002, p.298). Refreshments will be served to promote the comfort of the educators.. The program will be conducted in between monthly orientations for five days for eight hours with 30 minutes break time each day. The workshops will take place in a large classroom or a large conference room in one of the State's campuses. The state classrooms and conference rooms are conducive to learning and are technology-ready rooms.

\section{The Instructor's Notes}

- The instructor's notes should focus on encouraging the audience participation and time keeping.

- Give the background on Knowles's Andragogy vs. Pedagogy

- Mix the discussion groups to reflect different age groups and experience level

\section{LEARNING TASK TWO}

The second learning task is that the learners will observe and critique different classroom instructional techniques simulation. This task will support the educators in building and incorporating the information into their knowledge base of Knowles's Andragogy (Woo, Herrington, Agostinho \& Reeves, 2007). Many studies show that tasks that encourage learners to integrate the information they are studying seem to improve learning (Woo et al., 2007; Galbraith, 2004).

\section{Alignment With Outcomes and Objectives}

To be able to establish an alternative way to conduct the new employees' orientation, training appropriately to be for adult learners, participants will be able to observe and critique simulations of different classroom instructional techniques. These observations and evaluations will help them differentiate between what methods are appropriate for adult learners. 


\section{The Instructor's Notes}

- The instructors should encourage the participants to talk about their philosophy of education

- Ask probing questions about different instructional methods

- Be knowledgeable of alternative techniques and strategies for questioning and discussion

- Create a supportive educational environment that encourages students to take risks

\section{SECTION 3: PRACTICE AND FEEDBACK}

A vast array of instructional strategies will be used during the workshop. For the two learning tasks, interactive instruction strategies will be used. This type of strategy is very dependent on discussion and sharing of information among participants. This approach insists that students should learn intellectual and social skills from peers and teachers (Woo et al., 2007; Galbraith, 2004). The interactive instruction strategy permits for a variety of methods. This instructional methodology includes a discussion and cooperative learning (Sharon, 2010; Woo et al., 2007; Galbraith, 2004).

Discussion is a verbal way to examine a topic, a concept or experience. It helps to encourage group process and interaction; helps students to answer questions that are confusing about their worldview. It can involve open-ended or guided discussions (Baker, \& Clark, 2010). According to Blount (1999), discussions:

Can help students achieve a richer, deeper understanding of content and can make course content more relevant. They often increase the instructor's enjoyment. They can reveal the content of the course to be contingent, open, and poised between accepted knowledge and the unknown. Students become a more vital part of larger discussions within the discipline. They can foster a sense of community (para.2).

Another strategy will be cooperative learning. Cooperative Learning is an instructional strategy with specific elements that involves a structured form of group learning. Studies show that collaborative learning higher self-esteem higher achievement greater use higher reasoning greater ability work. According to Johnson, Johnson, and Holubc, 1994 "Cooperative learning is the instructional use of small groups through which students work together to maximize their own and each other's learning."

Two types of cooperative learning will be used. Formal cooperative learning is used for completion of group goals. It is formal because the educator facilitates and monitors the group. It can be used in conjunction with discussions within the group for any length of the period.

Informal cooperative learning is usually used to introduce subjects to participants. It involves minilectures and small group learning (Sharon, 2010). Cooperative learning has five components - positive interdependence, individual accountability, promotive interaction, social skills and group processing (Wlodkowski, 2008). According to Mason CTE (n.d.):

Collaborative learning fosters student learning because it is active, it values the diverse learning preferences that students bring to the classroom, and it acknowledges that learning is a social process that occurs in a relationship with others. Effective Cooperative learning requires intentionality; it is more than just asking students to work in groups. When successful, incorporating group work into the classroom offers the opportunity to engage in more challenging and ambitious projects. Moreover, it can provide students with essential collaborative skills that are valued in the workplace (para. $20 \& 21$ ).

\section{Learning Task One}

Discussion

After a mini-lecture to introduce Knowles's Andragogy, the New Jersey educator will be divided into groups of six. They will discuss Knowles's adult learning principles and how it will impact the new employees' orientation, training to be appropriate for adult learners. They will be instructed to brainstorm 
and develop ways to change the new employees' orientation using Knowles's model (See Appendix 9). The group will briefly present their ideas to the rest of the class. This discussion/brainstorming/project will help the participants to understand and simulate adult learning practice necessary for orientation modification (Galbraith, 2004). Additionally, it will assist them to get feedback from the instructor and their peers about their efficient use of Knowles's adult learning principles (Galbraith, 2004).

\section{Cooperative Learning}

During the group presentation to the class and the instructor, students have to formulate answers to questions asked by the educator about Knowles's Andragogy. Students have to share responses to the questions posed by other group members. Additionally, students while listening to a group member's answers to the same question, have to create a new well-developed answer to the questions posed by class members and the instructor. This type of learning will enable the student to process, consolidate, and retain more information learned, help the participants to understand and simulate adult learning practice necessary for orientation modification. Again, it will assist them to get feedback from the instructor and their peers about their efficient use of Knowles's adult learning principles (Wlodkowski, 2008; Mason CTE, n.d.).

\section{Instructor Responsibilities}

- Outline the topic to be discussed

- Set the amount of discussion time

- Determine the composition and size of the groups

- State the reporting or sharing techniques.

- Have excellent observation, listening, interpersonal, and intervention skills and abilities by both teacher and students.

- Be an expert of the teacher in structuring and developing the dynamics of the group.

- Provide immediate feedback to the groups

- Organize suitable formal groups for a specific project

- Guide activity

- Transcribe strategies

- Debrief activity

\section{Learner Responsibilities}

- Share answers and rationales

- Describe group process

- Evaluate possible answers and rationale that apply to the question in a given situation

- Discuss factors to be considered in the situation

- Exchange ideas and explain how factors will be addressed

- Explain strategies discussed

- Pose questions for discussion

- Have excellent observation, listening, interpersonal, and intervention skills and abilities.

- Direct groups to recognize ideas that helped group process

\section{Learning Task Two}

Discussion

After a mini-lecture to introduce different instructional techniques that support adult learning theory, the New Jersey educators will observe and critique classroom simulations of instructional techniques on their effectiveness of for adult education. The participants observe the classroom simulations of different instructional techniques and discuss with the instructor if there are appropriate for adult learning (See Appendix 11). This type of activity will enable the student to process, consolidate, and retain more information learned, and help the participants to understand and simulate adult learning practice necessary 
for orientation modification. Again, it will assist them to get feedback from the instructor and their peers about their accurate identification of appropriate instructional methods suitable for adult learning (Baker, \& Clark, 2010).

\section{SECTION 4: ASSESSMENT}

\section{Application Assignment}

To ensure that the participants can apply Knowles's Andragogy to their practice settings, they have to do a project-based presentation. According to Berliner (1992),

Intertwined with the cognitive components associated with projects are the motivational components inherent in projects. These include the fact that projects teach students to be mastery-oriented, not ability-oriented; they teach students to be learning-oriented rather than performance-oriented; and they teach students to be task-involved rather than egoinvolved... When there is some degree of choice for the students, project-based methods motivate students more than any other teaching method I know about (pp. 10-11).

The assignment will apply to both the learning task one and the learning task two. Participant group will be divided into two groups. Each group of three participants will develop a project-based presentation on the principles of Andragogy. For each presentation, the goal of the learners is to state and explain the five Knowles Andragogy and three instructional techniques that are appropriate for adult learners. The presentation will be assessed by the students' effective application of Knowles's Andragogy using the rubrics below (See Appendices 13, 14, ad 15).

Rubrics allow the adult learner to concentrate on important areas of the assessment. Also, rubrics reduce the confusion connected with unclear instructions. A rubric creates a map that students can use to achieve the best possible level of academic performance (Muirhead, 2002; Suskie, 2004).

\section{SECTION 5: EVALUATION}

\section{Summary}

Developing this project was very educational. I truly appreciated the comments and the unbiased feedbacks of my collaborative partners. Their different backgrounds, insights, and perspectives helped me to modify and develop my proposal. The feedback from my collaborative partners was effective because it is informational, prompt, definite and constructive (Wlodkowski, 2008).

The collaborative partners agreed that the proposal was good. However, they pointed out that I needed to be consistent with the APA style; to give more details about my instructional strategies; and to show with literature how the strategies would align the learning tasks with the program and learning objectives. Additionally, they enumerated how they would have enhanced the proposal. For instance, the recommended that the rubrics should include how the presentation will be graded; include how the group will be prepared prior to the presentation; and include the learners' evaluation of the group process and the presentations.

\section{Reflection}

During this process, I was lucky to have collaborative partners that were genuinely interested in my proposal. I had three intelligent and eager partners for my group. Ms. M is very smart, open-minded and a fellow nurse. As a faculty member at another school, she was a precious partner because she is also doing her doctorate online. Ms. H is an elementary school teacher. Having Ms. M as a partner did help me to get different perspectives on the project. Finally, Mr. O is a New Jersey administrator who is also pursuing his doctorate in a brick-and-mortar University. He is not only a stakeholder but also one of the decision-makers for my target audience. He was an invaluable partner. I am especially indebted to my "unofficial" collaborative partners, Dr. B, my husband and my son. 
Initially, I was apprehensive about working with collaborative partners. However, after going through this course, I am a strong proponent of the process. It is a way to encourage students to learn from their peers while learning critical thinking and other social skills. In my work/learning environment, I intend to use the different collaborative strategies such as cooperative learning, think-pair-share, cooperative learning and Jigsaw (Appendix 10-12). This collaborative project is an invaluable learning approach for adult learners. The process helped me to develop a higher level of thinking skills through discussions, weekly debates, written and verbal comments, the partners' interactions contributed to enhance my satisfaction with this learning experience; and to create an environment of active, involved, and exploratory learning. Additionally, the collaboration process helped me to develop my oral communication skills; social interaction skills; and interpersonal relationships with my partners. I realized that Wlodkowski (2008) was correct when he stated that collaborative learning helps to teach learners how to use a team approach to problem-solving while maintaining individual accountability.

\section{ACKNOWLEDGEMENT}

C2020 American Society for Engineering Education. ASEE Annual Conference Proceedings, June 2020, Virtual Conference

\section{REFERENCES}

Agency for Healthcare Research and Quality. (n.d.). Medical errors: the scope of the problem. Fact sheet. Publication No. AHRQ 00-P037. February 9, 2010, from http://www.ahrq.gov/qual/errback.htm.

Baker, T., \& Clark, J. (2010). Cooperative learning- a double edged sword: A cooperative learning model for use with diverse student groups. Intercultural Education, 21(3), 257- 268.

Barbazette, J. (n.d). Make New Employee Orientation a Success. Retrieved from http://www.ideasandtraining.com/New-Employee-Orientation-Article.html

Berliner, D.C. (1992). Redesigning classroom activities for the future. Educational Technology, 32(5), 713.

Blount, J.M. (1999). Leading Classroom Discussion. Retrieved from http://www.celt.iastate.edu/teaching/discussions.html

Cafferella, R. (2002). Planning programs for adult learners: A practical guide for educators, trainers and staff developers. San Francisco, Jossey-Bass.

Conti, G.J. (1998). Identifying Your Teaching Style (Ch. 4). In M.W. Galbraith (Ed.), Adult Learning Methods (2nd ed., pp. 73-84). Malabar, FL: Krieger Publishing Company.

Daffron, S., (2010). Facilitating adult learning. (DVD). Laureate Education, Inc Baltimore: Author.

Galbraith, M. (Ed.). (2004). Adult learning methods: A guide for effective instruction (3rd ed.). Malabar, FL: Kreiger Publishing.

Kerka, S. (2002). Teaching Adults: Is It Different? Myths and Realities. Retrieved from http://www.calpro-online.org/eric/docs/mr00036.pdf

Knowles, M.S., Holton, E.F., III, \& Swanson, R.A. (2005). The adult learner (6th ed.). New York, NY: Elsevier Publishing.

Lacey, L.M., \& Shaver, K. (2003). Spending Patterns for Nurse Overtime and Outside Staffing Among North Carolina Nurse Employers. North Carolina Center for Nursing- Quick Facts. Retrieved from http://www.NurseNC.org/research/demand.

Lieb, S. (1991) Principles of Adult Learning. Retrieved from http://intranet.hsgd.org/WebPage/Training\%20Web\%20Folders/Training\%20Web/ProgrammedL earning/PaperModules/AdultLearning_NoAnswers.pdf

Muirhead, B. (2002). Relevant Assessment Strategies for Online Colleges and Universities. USDLA Journal, 16(2). Retrieved from http://www.usdla.org/html/journal/FEB 02_Issue/article04.html

Nguyen, P.M., \& Terlouw, C., \& Pilot, A., \& Elliott, J. (2009). Cooperative learning that features a culturally appropriate pedagogy. British Educational Research Journal, 35(6), 857-873. 
Sharon, Y. (2010). Cooperative learning for academic and social gains: valued pedagogy, problematic practice. European Journal of Education, 45(2), 300-313.

Short, D.J., \& Echevarria, J. (1999). The Sheltered Instruction Observation Protocol: A Tool for TeacherResearcher Collaboration and Professional Development. Center for Applied Linguistics Online Resources: Digests. Retrieved from http://www.cal.org/caelanetwork/pdfs/ObservingProvidingFinalWeb.pdf

Special report! Helpful solutions for meeting the 2006 National Patient Safety goals. (2005). Joint Commission Perspectives on Patient Safety, 5(8), 1-15.

State of New Jersey Department of Human Services Website. (n.d.). Retrieved from http://www.state.nj.us/humanservices/home/about/

Suskie, L. (2004). Assessing Student Learning: A Common Sense Guide. Boston: Anker.

University of Wisconsin. (2006). Morale and Job Satisfaction Focus Group and Interview Report. Retrieved from http:// www. uwstout.edu/static/bpa/planning/ spgretreat/2006/morjobsat.pdf

Woo, Y., Herrington, J., Agostinho, S., \& Reeves, T.C. (2007). Implementing Authentic Tasks in WebBased Learning Environments: The instructor's inclusion of authentic activities improves the quality of student interaction and learning in online classrooms. Retrieved from $\mathrm{http} / / /$ www.educause.edu/EDUCAUSE+Quarterly/EDUCAUSEQuarterlyMagazineVolum/Imple mentingAuthenticTasksinWe/161831

\section{APPENDIX 1 \\ BIOGRAPHICAL SURVEY - LIKERT SCALE}

Dear Participant:

Thank you for your participating in this survey. The following worksheet captures faculty demographic information as well as solicits feedback on some things that a teacher of adults might do in a classroom. Please answer the comments with Strongly Agree, Agree, Slightly Agree, Slightly Disagree, and Strongly Disagree.

Please note that all your personal information is confidential. The results cannot be traced back to you. Please complete the survey and return to me at doccchichi@outlook.edu.

Thanks for your cooperation.

Faculty Name Number of years teaching

Age Gender: Male Female

Highest level of education: Masters $\mathrm{ABD}$ Ph.D. DBA/DM JD

Ethnicity: Caucasian African American Hispanic Asian Other

Highest level of education's program of study (Communication, Accounting, Nursing, Medicine et 
Number of years teaching at New Jersey State Department

Number of years working "in your chosen field"

Does current work position directly relate to the subject taught in this study?_Yes_No Times you have

previously conducted the new employee orientation

THANK YOU FOR YOUR PARTICIPATION IN AND SUPPORT OF THIS STUDY.

\section{APPENDIX 2 \\ FORMAL LIKERT SCALE SURVEY}

\begin{tabular}{|c|c|c|c|c|c|c|}
\hline \multirow{2}{*}{ Teaching Activities } & \multicolumn{6}{|c|}{ Rating } \\
\hline & $\begin{array}{c}6 \\
\text { Strongly } \\
\text { Agree }\end{array}$ & $\begin{array}{c}5 \\
\text { Agree }\end{array}$ & $\begin{array}{c}4 \\
\text { Slightly } \\
\text { Agree }\end{array}$ & $\begin{array}{c}3 \\
\text { Slightly } \\
\text { Disagree }\end{array}$ & $\begin{array}{c}2 \\
\text { Disagree }\end{array}$ & $\begin{array}{c}1 \\
\text { Strongly } \\
\text { Disagree }\end{array}$ \\
\hline $\begin{array}{l}\text { 1. I use disciplinary action when it is } \\
\text { needed. }\end{array}$ & & & & & & \\
\hline $\begin{array}{l}\text { 2. I encourage students to adopt } \\
\text { middle class values. }\end{array}$ & & & & & & \\
\hline $\begin{array}{l}\text { 3. I plan units, which differ widely } \\
\text { as possible from my students' } \\
\text { socio- economic backgrounds. }\end{array}$ & & & & & & \\
\hline $\begin{array}{l}\text { 4. I get a student to motivate } \\
\text { himself/herself by } \\
\text { confronting him/her in the } \\
\text { presence of classmates } \\
\text { during group discussions. }\end{array}$ & & & & & & \\
\hline $\begin{array}{l}\text { 5. I participate in the informal } \\
\text { counseling of students. }\end{array}$ & & & & & & \\
\hline $\begin{array}{l}\text { I gear my instructional } \\
\text { objectives to match the } \\
\text { individual abilities and needs } \\
\text { of the students. }\end{array}$ & & & & & & \\
\hline $\begin{array}{l}\text { 7. I encourage dialogue among my } \\
\text { students. }\end{array}$ & & & & & & \\
\hline $\begin{array}{l}\text { 8. I utilize the many } \\
\text { competencies that most adults } \\
\text { already possess to achieve } \\
\text { educational objectives. }\end{array}$ & & & & & & \\
\hline $\begin{array}{l}\text { 9. I avoid discussion of controversial } \\
\text { subjects that involve value } \\
\text { judgments. }\end{array}$ & & & & & & \\
\hline $\begin{array}{l}\text { 10. I help students relate new learning } \\
\text { to their prior experiences. }\end{array}$ & & & & & & \\
\hline
\end{tabular}




\section{APPENDIX 3 \\ INFORMAL SEMI-STRUCTURED INTERVIEW QUESTIONS FOR THE FOCUS GROUP PROCESS}

\section{Focus Group/Interview Questions}

PAST AND PRESENT

- How long have you been working for the state?

- What are your job responsibilities?

- Did you feel that you are well prepared by the state to do your job?

FUTURE

- Thinking ahead to the future, describe the ideal orientation to your at the state

- Reflecting on the ideas you just described, which of these aspects would have the greatest ACTIONS positive impact on your job satisfaction at the state?

- What can you do, individually, to make your ideal scenario a reality?

- Suppose you had the power to initiate changes at the orientation program, what would you do?

- Reflecting on the changes you just proposed, which of these changes would have the greatest positive impact on your job satisfaction?

- Of all the things we discussed today, what to you is the most important?

Do you have any additional comments? A comment card will also be handed out.

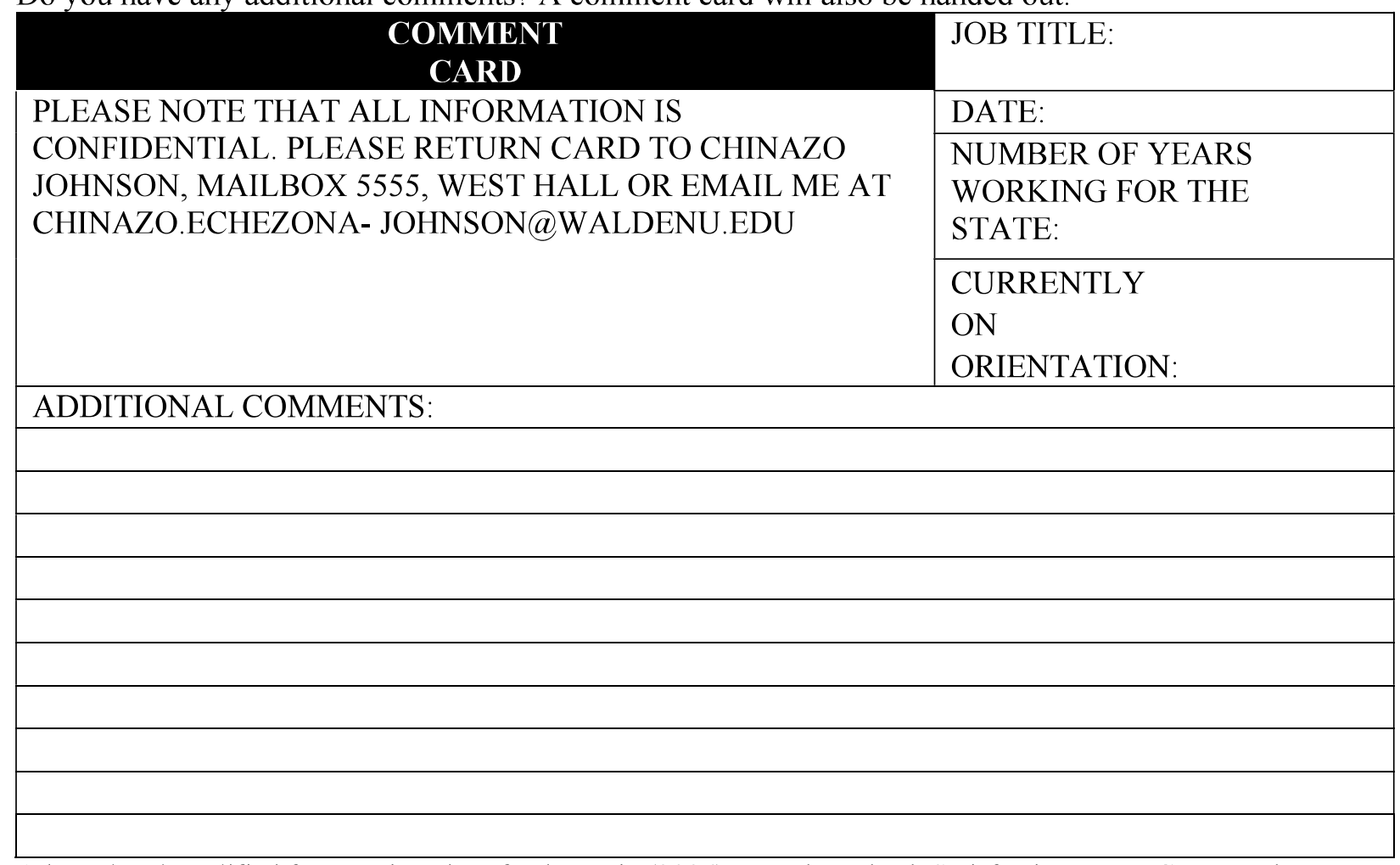

Adapted and modified from University of Wisconsin (2006). Morale and Job Satisfaction Focus Group and Interview Report. Retrieved August 2, 2010 from

http://www.uwstout.edu/static/bpa/planning/spgretreat/2006/morjobsat.pdf. 


\section{APPENDIX 4 \\ FORMAL OBSERVATION CHECKLIST}

Instructor

Observer

Setting:

Number of new employees:

check beside the activities observed. If the element was not covered, note

in the space beneath the element or under Observer's Comments.

Directions: Use this checklist for classroom observations. Place a

INSTRUCTIONAL

DEMONSTRATED ACTIVITIES(List

ACTIVITIES examples)

Provided review of previous work as warm-up exercise for students

Stated lesson objectives and reviewed the agenda

Provided opportunities for students to become familiar with

lesson materials

Checked students' background knowledge on the topic/lesson

Other

Used appropriate presentation style(s) for content and audience

Gave adequate/appropriate explanation of new concepts

Responded to students' questions

Answered questions immediately

Periodically checked students' comprehension

Other:

렁

Set up practice activities clearly

Gave examples and/or demonstrations

Monitored/assisted all students (individually, paired, and grouped)

variety of communicative strategies for practice of language skills

and content

Other:

Gave students time to apply what was learned

Gave students time to share their application (work)

Gave students an opportunity to comment/evaluate each other's

work, as appropriate

Other:

을

Evaluated students' application of concepts

Gave students an opportunity to evaluate the lesson, as appropriate

Other:

Gave students opportunities to review materials over time

Gave students opportunities to ask questions Orally or in writing

during class

Gave students a task to further investigate conten

Other:

\section{OBSERVER'S COMMENTS:}

Modified and adapted from Short, D.J. and Echevarria, J. (1999) The Sheltered Instruction Observation Protocol: A Tool for Teacher- Researcher Collaboration and Professional Development. Center for Applied Linguistics Online Resources: Digests. Retrieved August 4, 2010 from http://www.cal.org/caelanetwork/pdfs/ObservingProvidingFinalWeb.pdf 


\section{APPENDIX 5}

Title: Modification of new employee orientation for New Jersey Department of Health

Date and Time: Thursday, August $2010 \quad 9: 00$ am to 12:30 pm

\begin{tabular}{|c|c|c|c|c|}
\hline $\begin{array}{l}\text { Learning } \\
\text { Objectives }\end{array}$ & $\begin{array}{l}\text { Content } \\
\text { Heading }\end{array}$ & $\begin{array}{l}\text { Key points to } \\
\text { emphasize }\end{array}$ & $\begin{array}{c}\text { Instructional } \\
\text { techniques }\end{array}$ & $\begin{array}{l}\text { Estimated } \\
\text { Time }\end{array}$ \\
\hline $\begin{array}{l}\text { The participants will } \\
\text { be able to ... }\end{array}$ & & & & \\
\hline $\begin{array}{l}\text { Explain four adult } \\
\text { learning principles } \\
\text { and developmental } \\
\text { theories }\end{array}$ & $\begin{array}{l}\text { Adult learning } \\
\text { principles and } \\
\text { developmental } \\
\text { theories }\end{array}$ & $\begin{array}{l}\text { Discuss the } \\
\text { different theorists } \\
\text { and their } \\
\text { philosophy on } \\
\text { education }\end{array}$ & $\begin{array}{ll}\text { - } & \text { Lecture } \\
\text { - } & \text { Group } \\
\text { discussion }\end{array}$ & 90 minutes \\
\hline $\begin{array}{l}\text { Discuss six } \\
\text { instructional } \\
\text { techniques that } \\
\text { incorporate adult } \\
\text { learning principles }\end{array}$ & $\begin{array}{l}\text { instructional } \\
\text { techniques } \\
\text { and their } \\
\text { purposes }\end{array}$ & $\begin{array}{l}\text { Introduce different } \\
\text { instructional } \\
\text { techniques that } \\
\text { incorporate adult } \\
\text { learning principles }\end{array}$ & $\begin{array}{ll}\text { - } & \text { Lecture } \\
\text { - } & \text { Reflective } \\
& \text { practice } \\
\text { - } & \text { Simulations }\end{array}$ & 60 minutes \\
\hline $\begin{array}{l}\text { Demonstrate three } \\
\text { ways to motivate the } \\
\text { adult learner }\end{array}$ & $\begin{array}{l}\text { Motivating } \\
\text { the adult } \\
\text { student }\end{array}$ & $\begin{array}{l}\text { Discuss and } \\
\text { demonstrate } \\
\text { different ways to } \\
\text { motivate the adult } \\
\text { learner }\end{array}$ & $\begin{array}{ll}\text { - } & \text { Problem } \\
\text { based } \\
\text { learning } \\
\text { - } & \text { observations }\end{array}$ & 45 minutes \\
\hline
\end{tabular}

Assessment Plan: Observations, Role playing, self-report evaluation forms.

\section{Instructional resources and equipment needed:}

\section{For Instructor}

PowerPoint presentation

Posters

LCD panels

\section{Room Arrangement Needed:}

\section{For Participants}

Reference lists

Handouts

Articles

Team style arrangement with seats of five around oblong tables. 
APPENDIX 6

PROGRAM BUDGET

\begin{tabular}{|c|c|}
\hline \multicolumn{2}{|l|}{ Salary } \\
\hline 2 External instructors/facilitators (2@\$100/hr for 4 hours) & $\$ 800$ \\
\hline 1 Technology specialist (1@ \$50/hr) & $\$ 200$ \\
\hline Internal staff for clerical duties, focus groups and evaluation & $\$ 0$ \\
\hline \multicolumn{2}{|l|}{ (supplied by the State) } \\
\hline 2 graduate students $(2 @ \$ 20 / \mathrm{hr}$ for 5 hours $)$ & $\$ 200$ \\
\hline Total Salary & $\$ 1000$ \\
\hline \multicolumn{2}{|l|}{ OPERATING } \\
\hline Travel (for external staff) ( $\$ 150 /$ per staff) & $\$ 750$ \\
\hline Refreshments (Coffee and Bagels) & $\$ 100$ \\
\hline \multicolumn{2}{|l|}{ Communication } \\
\hline Telephone (supplied by State) & $\$ 0$ \\
\hline Internet (supplied by State) & $\$ 0$ \\
\hline \multicolumn{2}{|l|}{ Supplies } \\
\hline Duplicating (supplied by State) & $\$ 0$ \\
\hline Equipment (supplied by State) & $\$ 0$ \\
\hline Marketing Plans (supplied by State) & $\$ 0$ \\
\hline \multicolumn{2}{|l|}{ Facilities } \\
\hline Classroom, lecture halls (supplied by State) & $\$ 0$ \\
\hline Other costs & $\$ 50$ \\
\hline TOTAL OPERATING & $\$ 900$ \\
\hline TOTAL DIRECT COSTS & $\$ 1850$ \\
\hline INDIRECT COST & $\$ 50$ \\
\hline TOTAL PROJECT & $\$ 2000$ \\
\hline
\end{tabular}




\section{APPENDIX 7 \\ FORMAL LIKERT SURVEY SCALE}

\section{Participant Questionnaire for Transfer of Learning}

Title of Program: Modification of the New Employees Orientation

Date:

Please assist us in evaluating the quality of the transfer activities by completing this questionnaire. Your specific comments and

suggestions for improvement are also appreciated. For each question, circle the number that best represents your view:

$1=$ No 2=Somewhat $\quad 3=$ Yes, definitely

1. Were the guidelines clear as to what constitutes successful learning transfer

2. Did the instructor or facilitator use techniques that helped you apply what you had learned

3. Please specify who assisted you and what they did in helping you to apply what $\begin{array}{llll}1 & 2 & 3\end{array}$ you had learned to your setting

4. How do you rate the transfer part of the program

5. Please indicate which transfer techniques you used, and whether they were helpful in applying what you have learned

- Individual learning plan

- Mentoring

- Coaching

- Follow-up sessions

- Support group

- Networking

- Reflective practice

- Other(s); please specify

Which techniques were most helpful and why?

program and changes you would recommend Please comment on the major strengths of the transfer portion of the Major strengths:

Suggestions for improvement

Any additional observations/suggestions: 


\section{APPENDIX 8 \\ FORMAL LIKERT SURVEY SCALE}

\section{PARTICIPANT QUESTIONNAIRE}

Title of the Program: Modification of the New employees Orientation

Date:

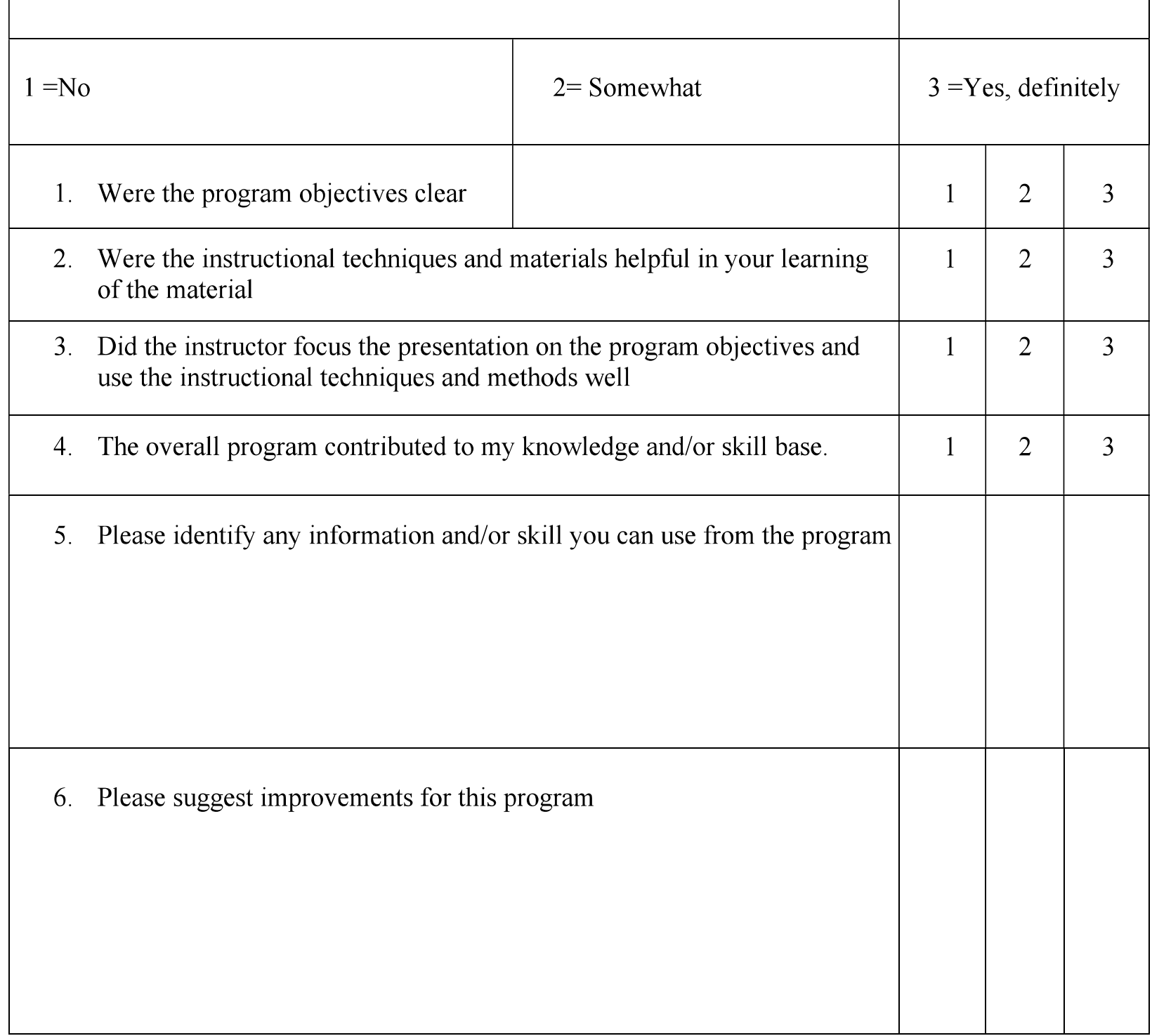

Adapted from: Cafferella, R. (2002). Planning programs for adult learners: A practical guide for educators, trainers and staff developers. San Francisco, Jossey-Bass. 


\section{APPENDIX 9 \\ BRAINSTORM}

Purpose: To get a lot of concepts out so that they can be analyzed.

Time Instructor Activities

\begin{tabular}{|l|l|l|l|}
\hline $30 \mathrm{~min}$ & $\begin{array}{l}\text { Identify elements of } \\
\text { Andragogy Guide activity }\end{array}$ & $\begin{array}{l}\text { Identify information known } \\
\text { about Knowles's Andragogy }\end{array}$ & $\begin{array}{l}\text { Flipchart, felt pens, } \\
\text { whole or small group }\end{array}$ \\
\hline $30 \mathrm{~min}$ & $\begin{array}{l}\text { Collect and comment on connections } \\
\text { Debrief activity }\end{array}$ & $\begin{array}{l}\text { Identify how previous information fits } \\
\text { Identify how understanding is increased }\end{array}$ & Whole group \\
\hline
\end{tabular}

\section{Activity - Brainstorm and \\ Analyze}

Organizer: This is a way to get a lot of ideas out about establishing an alternative way to conduct the new employees' orientation; training that will be appropriate for adult learners.

Objective: Identify information known and ideas about Knowles's adult learning principles and integrate it with new.

Time: $\quad 60$ minutes

Techniques / Equipment: Personal experience, written information, flipchart, felt pens. Monitor and encourage participation. Augment ideas to ensure comprehensive

list.

Process: In pairs or triads:

- Brainstorm the various types of ways to effectively modify the orientation to be appropriate for adult learners. This is an all ideas are welcome, no analysis session.

- Record the information.

In the whole group:

- Share the examples of effective orientation for adult learners from each group, rotating the response so that everyone contributes.

- Document on a flipchart.

- Discuss ideas that are triggered by the examples.

- Use examples and documented information to expand on their ideas.

Group Success: Everyone in the group can explain the ideas put forward.

Accountability: Identify how previous information fits into the expanded information. Debrief: Identify how what was known already assists understanding of newmaterials. 


\section{APPENDIX 10 \\ JIGSAW}

\begin{tabular}{|c|c|c|c|}
\hline Time & Instructor Activities & Learner Activities & Techniques / Equipment \\
\hline $\begin{array}{l}30 \\
\min \end{array}$ & $\begin{array}{l}\text { Form groups and present written information } \\
\text { Guide activity }\end{array}$ & Learn and rehearse materials & $\begin{array}{l}\text { Expert groups, segmented } \\
\text { information }\end{array}$ \\
\hline $\min$ & Ensure major points are correct & $\begin{array}{l}\text { Teach materials to others } \\
\text { Learn new material }\end{array}$ & Home groups \\
\hline $\min$ & Debrief activity & Identify group process & Individually, whole group \\
\hline
\end{tabular}

Purpose: To require that students interdependently learn from one another.

\section{Activity - Jigsaw}

Organizer: Students are assigned to small heterogeneous teams, and the materials to be learned are divided into as many sections as there are team members. First, members of the different teams who have the same section form "expert" groups and study together. Each then returns to his or her team and teaches that section to his or her teammates.

Objective: $\quad$ Use expert groups to cognitively rehearse information. Time: $\quad 90$ minutes

Techniques / Equipment: Segmented information. Monitor and encourage participation. Ensure accuracy. Process: Working in expert groups of three or four:

- Half of the groups take the information on Knowles's Andragogy and the other half take the information on establish an alternative way to conduct the new employees' orientation; training that will be appropriate for adult learners.

- Discuss and summarize the major points of the material.

- Use cognitive rehearsal in the groups to prepare to teach their part to a partner from another group.

In pairs formed with one person from each expert group:

- The expert will explain their portion to their partner so that they understand it clearly.

Group Success: Everyone in the group can explain the material.

Accountability: Question to random members of the home group regarding non-expert information comprehension and retention. Or, a short test on the information will be given to ensure that the material has been learned. Using the points above, have the participants write a short description under each heading.

Debrief: How did the explanations of others and your questions assist in understanding the material? 


\section{APPENDIX 11 \\ DISCUSSION - SMALL GROUP - KNOWLEDGE}

Purpose: To clarify characteristics of things or systems

\begin{tabular}{|c|c|c|c|}
\hline Time & Instructor Activities & Learner Activities & $\begin{array}{l}\text { Techniques } \\
\text { / } \\
\text { Equipment }\end{array}$ \\
\hline $35 \mathrm{~min}$ & $\begin{array}{l}\text { Identify the elements of } \\
\text { Knowles's Andragogy Guide } \\
\text { activity }\end{array}$ & $\begin{array}{l}\text { Discuss Knowles's Andragogy } \\
\text { and the observed classroom } \\
\text { instructional techniques } \\
\text { simulation. }\end{array}$ & Small groups \\
\hline $20 \mathrm{~min}$ & $\begin{array}{l}\text { Collect information. } \\
\text { Debrief activity }\end{array}$ & $\begin{array}{l}\text { Describe characteristics of } \\
\text { materials } \\
\text { Describe group process }\end{array}$ & Whole group \\
\hline
\end{tabular}

Activity - Discussion - Knowledge

Organizer: observe and critique different classroom instructional techniques simulation.

Objective: Discuss the characteristics of Knowles's Andragogy and the observed classroom instructional techniques simulation.

Time: 55 minutes

Techniques / Equipment: Personal experience, written information on observed simulation, Monitor and encourage participation and the exchange of ideas.

Process: In groups of three or four:

-Read characteristic

-Expand characteristic with a description

-Provide an observable consequence.

-Are there other characteristics? Add them

Group Success: Everyone in the group can explain the characteristics.

Accountability: Describe each characteristic by randomly calling on members to report on group activity

Debrief: How did your group members add to your knowledge? (Retrieved from Mason CTE, n.d.) 


\section{APPENDIX 12 \\ THINK-PAIR-SHARE}

Purpose: $\quad$ To ensure maximum discussion within a group.

\begin{tabular}{|c|c|c|c|}
\hline Time & Instructor Activities & Learner Activities & $\begin{array}{l}\text { Techniques/ } \\
\text { Equipment }\end{array}$ \\
\hline $30 \mathrm{~min}$ & $\begin{array}{l}\text { Present simulation on current } \\
\text { orientation of new } \\
\text { employees Guide activity }\end{array}$ & $\begin{array}{l}\text { Share information on and feelings } \\
\text { about simulation }\end{array}$ & $\begin{array}{l}\text { Think-Pair-Share; } \\
\text { written materials }\end{array}$ \\
\hline $30 \mathrm{~min}$ & $\begin{array}{l}\text { Collect and comment on } \\
\text { information } \\
\text { Debrief activity }\end{array}$ & $\begin{array}{l}\text { Share information and feelings } \\
\text { Discuss aids to process }\end{array}$ & Whole group \\
\hline \multicolumn{4}{|c|}{$\begin{array}{l}\text { Activity - Think-Pair-Share } \\
\text { Organizer: Increases the discussion on establish an alternative way to conduct the new } \\
\quad \text { employees' orientation; training that will be appropriate for adult learners. } \\
\text { Objective: Share information on and feelings about current orientation of new employees } \\
\text { Time: } 60 \text { minutes } \\
\text { Techniques / Equipment: Details of a case, situation or question. Monitor and encourage } \\
\text { participation. Process: Individually: Think about current orientation of new employees and the } \\
\text { implications. } \\
\text { In pairs: Discuss the situation and your thoughts around the situation } \\
\text { Group Success: Both people can explain the point of view of the other. } \\
\text { Accountability: Share the information and personal feelings about current orientation of new } \\
\text { employees with others. } \\
\text { Debrief: Identify how discussing the situation added to how well you could identify your } \\
\text { feelings about the situation. Identify how sharing information added to how well you } \\
\text { know the material. }\end{array}$} \\
\hline
\end{tabular}

\section{APPENDIX 13 \\ TO MAKE A PRESENTATION}

Purpose: To support a presentation before it is made.

\begin{tabular}{|c|c|c|c|}
\hline Time & Instructor Activities & Learner Activities & $\begin{array}{l}\text { Techniques / } \\
\text { Equipment }\end{array}$ \\
\hline $20 \mathrm{~min}$ & $\begin{array}{l}\text { Set up situation for the preparation } \\
\text { of the outline }\end{array}$ & $\begin{array}{l}\text { Identify elements necessary to } \\
\text { make } \\
\text { a presentation outline }\end{array}$ & Small group \\
\hline $\begin{array}{l}330 \\
\min \end{array}$ & $\begin{array}{l}\text { Identify project teams Guide } \\
\text { project }\end{array}$ & $\begin{array}{l}\text { Develop a presentation. } \\
\text { Revise with feedback }\end{array}$ & $\begin{array}{l}\text { Formal groups var. } \\
\text { Resources }\end{array}$ \\
\hline $60 \mathrm{~min}$ & $\begin{array}{l}\text { Identify areas of process to } \\
\text { document }\end{array}$ & Document the group process & Formal groups \\
\hline $60 \mathrm{~min}$ & Review the presentation & $\begin{array}{l}\text { Make a presentation to a } \\
\text { Workshop participants/ New } \\
\text { Jersey educators }\end{array}$ & $\begin{array}{l}\text { Formal groups, target } \\
\text { group }\end{array}$ \\
\hline $10 \mathrm{~min}$ & Debrief activity & Identify group process & Whole group \\
\hline
\end{tabular}




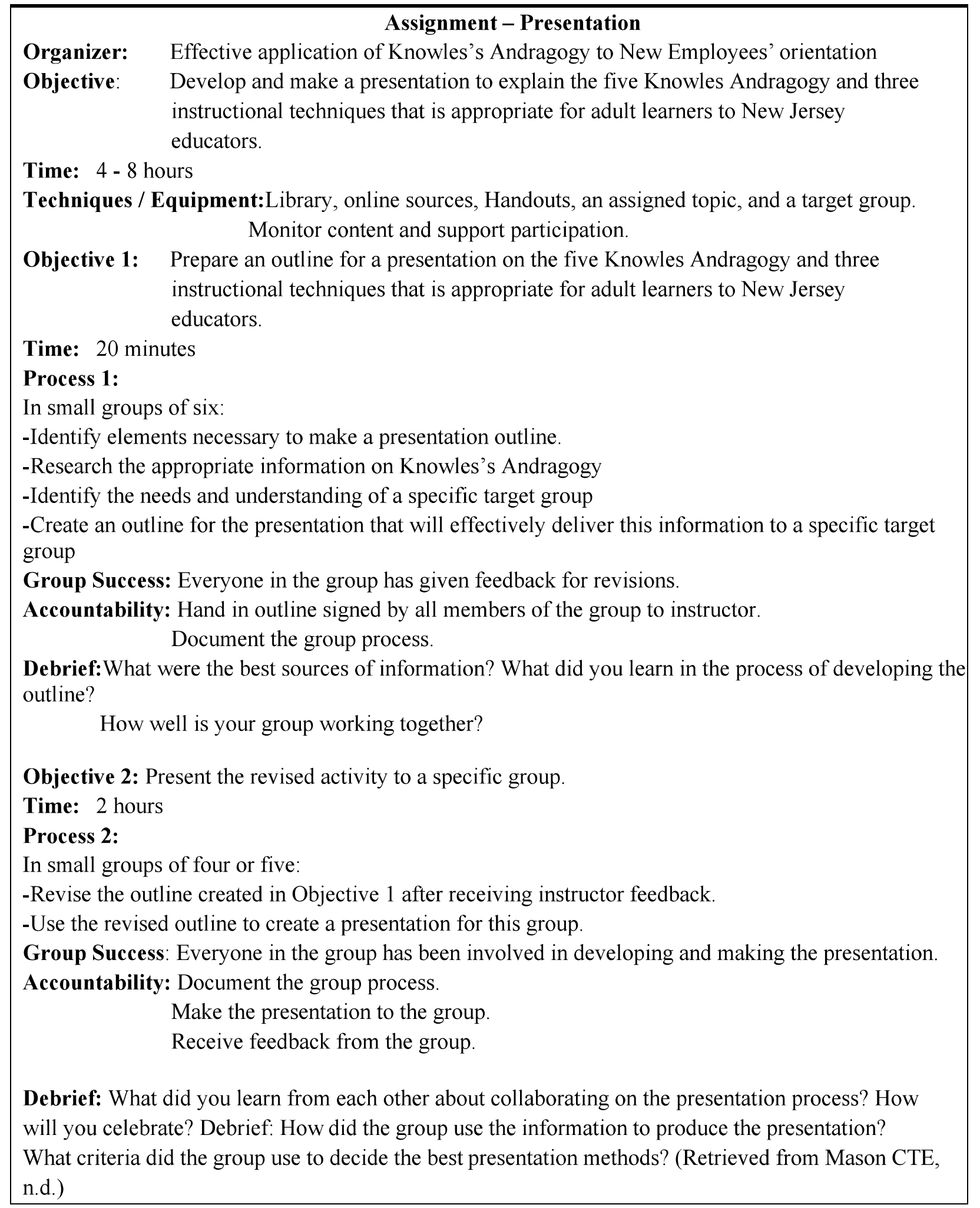




\section{APPENDIX 14}

\section{Evaluation for Group Presentation}

As you know, part of your final grade is based upon your participation in and contribution to your study groups. To help me determine your grade and assign these points, I ask that you provide information that evaluates the performance of your study group members and yourself. Keep in mind that the information you provide here is confidential, as only I will see this evaluation. Please think about what you have learned about working effectively in groups. Consider the following five criteria as you rate yourself and your group members:

- Effort/Active Participation: Following through on assignments and being accountable to group members

- Contribution: Improving quality of work, being creative, bringing unique skills and abilities that aid in the quality of the final product, and providing leadership

- Supported Group Process: Eliciting and valuing input of others, making room for quiet members or not overshadowing others, mediating arguments and relieving tension, lending a positive attitude, and other maintenance roles that enhance group social climate

- Communication: Checking in with group before missing a meeting, clarifying expectations, keeping communication channels open, facilitating others' participation, and speaking/listening effectively

- Attendance: Attending group meetings, afternoon phase work, and seminar group work

Using each of the above criteria, provide a rating for yourself and each of your group members. Use the rating scale below. In the last column I ask that you recommend a grade, for example, A, B-, C+, D, F, etc.

\begin{tabular}{|c|c|c|c|c|c|}
\hline \multirow{2}{*}{ NAME } & \multicolumn{5}{|c|}{ 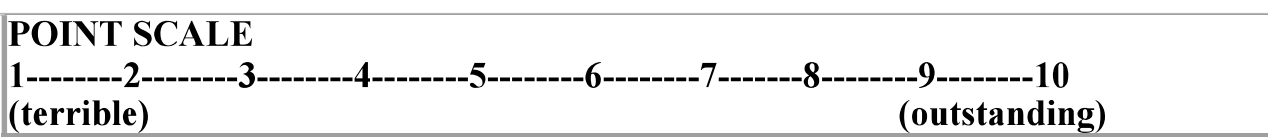 } \\
\hline & $\begin{array}{l}\text { Effort/Active } \\
\text { Participation }\end{array}$ & Contribution & $\begin{array}{l}\text { Supported } \\
\text { Group } \\
\text { Process }\end{array}$ & Communication Attendance & Grade \\
\hline \multicolumn{6}{|l|}{ Yourself: } \\
\hline \multicolumn{6}{|l|}{ Group member 1: } \\
\hline \multicolumn{6}{|l|}{ Group member 2: } \\
\hline \multicolumn{6}{|l|}{ Group member 3} \\
\hline \multicolumn{6}{|l|}{ Group member 4: } \\
\hline Group member 6: & & & & & \\
\hline & & & & & \\
\hline
\end{tabular}


In addition, please write a separate paragraph about yourself and each group member that explains your reasons for the ratings above. Be sure to use the criteria above and to provide specific information, positive and negative, that will provide evidence for and support your ratings.

Explanation and Justification of Self-Rating:

Explanation and Justification of Rating for:

Explanation and Justification of Rating for:

Explanation and Justification of Rating for:

Explanation and Justification of Rating for:

\section{Please answer these questions:}

Give one specific example of something you learned from the group that you probably would not have learned on your own. 


\section{APPENDIX 15 \\ PROJECT-BASED LEARNING RUBRIC}

In this rubric you will find evaluation criteria for the presentation. Note that the following criteria are assessed in this rubric:

- Content

- Organization
- Presentation

- Scholarly Writing

\begin{tabular}{|c|c|c|c|c|c|}
\hline \multicolumn{2}{|c|}{$\begin{array}{l}\text { Score } \\
\text { Levels }\end{array}$} & Content & Scholarly Writing & Organization & Presentation \\
\hline 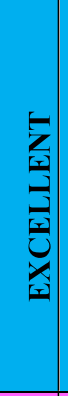 & 4 & $\begin{array}{l}\text { Is well thought out and explains } \\
\text { the five Knowles Andragogy and } \\
\text { three instructional techniques that } \\
\text { are appropriate for adult learners. } \\
\text { Has clear goal that is related to the } \\
\text { topic } \\
\text { - Reflects application of } \\
\text { critical thinking } \\
\text { - Is pulled from a variety of up-to- } \\
\text { date sources }\end{array}$ & $\begin{array}{l}\text { No spelling, } \\
\text { grammatical, or } \\
\text { punctuation errors } \\
\text { - High-level use of } \\
\text { vocabulary and } \\
\text { word choice }\end{array}$ & $\begin{array}{l}\text { - Information is } \\
\text { clearly focused in } \\
\text { an organized and } \\
\text { thoughtful manner. } \\
\text { - Information is } \\
\text { constructed in a } \\
\text { logical pattern. }\end{array}$ & $\begin{array}{l}\text { - Multimedia is used to } \\
\text { clarify and illustrate the } \\
\text { main points. } \\
\text { - Format enhances the } \\
\text { content. } \\
\text { - Presentation captures } \\
\text { audience attention. } \\
\text { - Presentation is } \\
\text { organized and well laid } \\
\text { out. }\end{array}$ \\
\hline 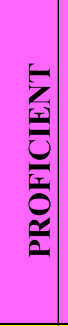 & 3 & $\begin{array}{l}\text { - Explains the five Knowles Andragogy } \\
\text { and three instructional techniques that } \\
\text { are appropriate for adult learners. Has } \\
\text { clear goal that is related to the topic } \\
\text { - Has application of critical } \\
\text { thinking that is apparent } \\
\text { - Is pulled from several sources }\end{array}$ & $\begin{array}{l}\text { - Few (1 to 3) } \\
\text { spelling, } \\
\text { grammatical, or } \\
\text { punctuation } \\
\text { errors } \\
\text { - Good use of } \\
\text { vocabulary and } \\
\text { word choice }\end{array}$ & $\begin{array}{l}\text { - Information is } \\
\text { clearly focused in } \\
\text { an organized and } \\
\text { thoughtful manner. } \\
\text { - Information is } \\
\text { constructed in a } \\
\text { logical pattern }\end{array}$ & $\begin{array}{l}\text { - Multimedia is used to } \\
\text { illustrate the main points } \\
\text { - Format is appropriate } \\
\text { for the content. } \\
\text { - Presentation captures } \\
\text { audience attention. } \\
\text { - Presentation is well } \\
\text { organized. }\end{array}$ \\
\hline 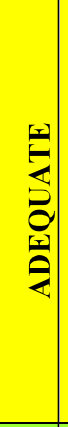 & 2 & $\begin{array}{l}\text { Explains some of the five } \\
\text { Knowles Andragogy and three } \\
\text { instructional techniques that are } \\
\text { appropriate for adult learners. Has } \\
\text { no clear goal } \\
\text { - Has application of critical } \\
\text { thinking that is apparent } \\
\text { - Is pulled from a limited number } \\
\text { of sources } \\
\text { - Has some factual errors } \\
\text { or inconsistencies }\end{array}$ & $\begin{array}{l}\text { - Minimal (3 to 5) } \\
\text { spelling, grammatical, } \\
\text { or punctuation errors } \\
\text { - Low-level use of } \\
\text { vocabulary and } \\
\text { word choice }\end{array}$ & $\begin{array}{l}\text { - Project has a focus } \\
\text { but might stray } \\
\text { from it at times. } \\
\text { - Information appears } \\
\text { to have a pattern, but } \\
\text { the pattern is not } \\
\text { consistently carried } \\
\text { out in the project. } \\
\text { - Information } \\
\text { loosely supports } \\
\text { the solution. }\end{array}$ & $\begin{array}{l}\text { - Multimedia loosely } \\
\text { illustrates the main } \\
\text { points. } \\
\text { - Format does not } \\
\text { suit the content. } \\
\text { - Presentation does not } \\
\text { capture audience } \\
\text { attention. } \\
\text { - Presentation is } \\
\text { loosely } \\
\text { organized. }\end{array}$ \\
\hline 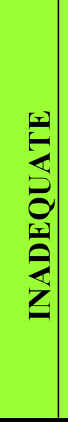 & 1 & $\begin{array}{l}\text { Provides inconsistent information } \\
\text { about the five Knowles Andragogy } \\
\text { and three instructional techniques } \\
\text { that are appropriate for adult } \\
\text { learners. Has no clear goal } \\
\text { - Has no apparent application of } \\
\text { critical thinking } \\
\text { - I pulled from few sources } \\
\text { - Has significant factual errors, } \\
\text { misconceptions, or } \\
\text { misinterpretations }\end{array}$ & $\begin{array}{l}\text { - More than } 5 \\
\text { spelling, } \\
\text { grammatical, or } \\
\text { punctuation } \\
\text { errors } \\
\text { - Poor use of } \\
\text { vocabulary and } \\
\text { word choice }\end{array}$ & $\begin{array}{l}\text { - Content is unfocused } \\
\text { and haphazard. } \\
\text { - Information } \\
\text { has no } \\
\text { apparent } \\
\text { pattern. }\end{array}$ & $\begin{array}{l}\text { - Presentation appears } \\
\text { sloppy and/or } \\
\text { unfinished. } \\
\text { - Multimedia is } \\
\text { overused or } \\
\text { underused. } \\
\text { - Format does not } \\
\text { enhance content. } \\
\text { - Presentation has no } \\
\text { clear organization. }\end{array}$ \\
\hline & & & & & $\begin{array}{l}\text { TOTAL } \\
\text { POINTS }\end{array}$ \\
\hline
\end{tabular}

There are four criteria included in this rubric $\mathrm{X} 25$ points maximum for each $=100$ possible total points for the project. 